\title{
Landscaping, Landscape Legacies, and Landesque Capital in Pre-Columbian Amazonia
}

Manuel Arroyo-Kalin

To be published in: The Oxford Handbook of Historical Ecology and Applied Archaeology, Edited by Christian Isendahl and Daryl Stump. DOI: 10.1093/oxfordhb/9780199672691.013.16

\begin{abstract}
Keywords
How do human and landscape histories reciprocally affect each other? Can we distinguish between deliberate and unintended anthropic transformations of the landscape? This chapter summarizes evidence from pre-Columbian Amazonia in order to discuss the relation between three dimensions of anthropic landscape transformations: landscaping, landscape legacies, and landesque capital. Conflation between these three categories can lead to theoretical road closures and certainly risks oversimplifying both causality and consequence when anthropic landscape modifications are considered. On the other hand, paying attention to their differences defines a rich field of research in which historical ecology, earth-scientific thinking, and human niche construction theory converge.
\end{abstract}

Keywords: Amazonia, historical ecology, landscaping, landesque capital, landscape legacies, human niche construction

\section{Introduction}

The development of historical ecological thinking (Balée, 1998; Crumley, 1994), the formulation of human niche construction theory (Laland et al., 2000; Smith 2007), and the growth of Anthropocene studies (e.g. Ellis et al., 2013; Smith and Zeder 2013; cf. Doolittle, this volume) have in recent years renewed the confidence of research efforts focused on understanding how past histories of human inhabitation have led to specific trajectories of landscape change (Brown et al., 2013; Butzer, 1982; French, 2003; van der Leeuw and Redman, 2002). These efforts include attempts to elucidate the enduring effects of human inhabitation on past environments as well as efforts to study the extensive record of landed infrastructure associated with past settlement, food production, and transportation. Both human impact and human engineering are increasingly relevant to interpretations about past demography and social complexity (Erickson, 2008; Håkansson and Widgren, 2014; Marcus and Stanish, 2006; Wilkinson, 2003).

At the intersection between these research foci, two major challenges emerge. First is the need to establish the extent to which features in the landscape are outcomes of human agency. Whilst in some cases this seems straightforward, in others it depends on the extent to which specific landscape features diverge from those that might have been produced by the landscape system without human intervention (Arroyo-Kalin 2014b). A second challenge-one of the main topics this 
chapter will examine-is to establish whether putative anthropic modifications of landscapes are a result of deliberate human behaviour, an incidental outcome of cumulative changes induced by past human impact, or both. A similar question was tackled by Eidt (1985), who distinguished between anthropogenic soils (those deliberately modified by humans) and anthropic soils (those whose properties record the effects of past land-use). His terminology, however, was not widely adopted, encountered practical limitations, and-by encouraging adjudication between one or the otheroften led researchers to a dead end.

The distinction between effects on the environment desired by past human communities and the legacy effects of past human communities on the environment is subtle but important. It continues to raise important questions about the ways in which human and landscape histories reciprocally affect each other. These questions define a rich field of research about the ways in which human and landscape histories intertwine beyond the temporal scale of a few human generations. To illustrate the scope of this field, I first turn to the evidence for anthropic landscape transformations in the Amazonian biome, an important region for the history of ideas of historical ecology (Balée, 2013). Following a brief review of different pre-Columbian examps, I highlight the extent to which we can consider these to be deliberate outcomes of past human action, legacies of past human impact, or both. I then discuss some of the implications that follow for our understandings of landscape evolution, human niche construction, and landesque capital.

\section{Amazonia: Human-Made or Human-Impacted?}

Over the past three decades Amazonian scholarship has rejected the suggestion that the 'environment' was an over-determining baseline which somehow was impervious to transformation by pre-Columbian human populations (Balée, 2006; Stahl, 1996). Instead, researchers from different disciplines have contributed to the recognition that pre-Columbian human societies played a crucial role in shaping the long-term properties of the Amazonian biome (Clement et al., 2015; Roosevelt, 2013). Three broad topics emerge: landscape engineering, environmental manipulation associated with domesticated and wild plant use, and the formation of anthropic soils.

\section{Landscape Engineering}

Amazonia is home to an impressive array of earth surface modifications that can be grouped under the broad label of pre-Columbian engineering of the landscape (Fig. 1). These include different types of earthworks - ditches, shell mounds, earth mounds, roads, raised/drained fields, reservoirs, artificial forest islands - that have helped colonize and transform flooding landscapes rich in aquatic resources, intensify crop production, establish special-purpose sites away from settlements, support populations living away from critical water resources, and implant transportation networks and defensive infrastructures. Examples include the presence of rectangular and circular bank-and- ditch features along a wide arc connecting the state of Acre to the headwaters of the Xingú River, in the southern periphery of the Amazon basin. Researchers believe that some of these precincts (Fig. 1b) were special-purpose sites of considerable size. Others would have surrounded pre-Columbian 
settlements of different size, from small villages to proto-urban aggregations. In both cases they would have been linked by multiple roads and causeways (Heckenberger, 2008; Lombardo and Prümers, 2010; Schaan, 2011). On the Belterra Plateau, near Santarém, Brazil, as well as the Llanos de Mojos, Bolivia, recent research has shown the presence of water reservoirs associated with preColumbian settlements (Lombardo and Prümers, 2010; Stenborg et al., 2014). Along the main reaches of the middle and lower Amazon region, as well as the lower Madeira River, evidence has emerged of large pre-Columbian settlements which are ringed by defensive ditches (Fig. 1e) and contain earth mounds variously used as house platforms or cemeteries (Heckenberger et al., 1999; Moraes and Neves, 2012). Research on Marajó Island shows that large habitation mounds and fish dams were created by excavation and earth-moving in the seasonally flooded savannah (Roosevelt, 1991; Schaan, 2008). In the Ecuadorian Amazon, raised platforms forming complex settlement layouts were erected by sub-Andean societies (Fig. 1C), only to be reused subsequently as house platforms by lowland peoples expanding into the region (Rostain, 2012). Beyond the Amazonian rainforest, in different lowland landscapes characterized by flooding savannah (the Llanos del Mojos, the Guianas, the Venezuelan Llanos), large habitation mounds were built using different techniques, whilst raised agricultural fields (Figs. 1a and 1d) and canals were used to intensify crop cultivation (Erickson, 2008; Lombardo and Prümers, 2010; Rostain, 2008; Spencer and Redmond, 2004).

The size, scale, and ubiquity of these anthropogenic landscape features highlight the range of modifications to the Amazonian landscape that were deliberately produced by pre-Columbian human communities. It is still unknown whether some of these features - for instance extensive areas with raised or drained fields - were constructed rapidly as a result of coordinated labour or shaped slowly as an outcome of multiple small-scale interventions (Erickson, 2006b). One way or the other, these forms of landscape modification endured over time and thus not only shaped the lives of their makers or their immediate descendants but also the lives of peoples that subsequently inhabited these regions (Fig. 2c). Or, if we return to Eidt's (1985) terminology, we might say that these constitute anthropogenic landscape transformations that over time have shaped enduring anthropic landscape legacies.

Studies of the fossil plant record and the distribution of extant wild relatives in Amazonia suggest that many pre-Columbian human populations relied for subsistence on plant cultivars, some originally domesticated in the Amazon basin and others originating from far away regions (Clement et al., 2010; Pickersgill, 2007; Piperno and Pearsall, 1998). The relative importance of today's most salient native crop-Manihot esculenta-is currently under discussion (Arroyo-Kalin, 2010; Neves, 2013), whilst the allochthonous crop Zea mays - sensitive to specific cropping conditions-may have been a significant staple in a number of different environmental contexts (Iriarte and Dickau, 2012). At least one Amazonian palm tree species, Bactris gasipaes, was domesticated (Clement et al., 2009). In addition, well over one hundred other plant species-among them numerous palms and fruit trees-were targeted for their edible parts or other economic uses (Clement, 2006; MorcoteRíos et al., 2014; Shepard and Ramirez, 2011; Smith, 2014). To judge from the ethnographic record, this enormous variety of cultivars and attractive plant species were managed through an equally varied set of practices of environmental alteration (Balée, 1989; Politis, 1996; Posey, 1985). On one end of the spectrum is swidden cultivation (Arroyo-Kalin, 2012; Beckerman, 1987; Harris, 1971), which aside from being the most common form of small-scale farming also functions as a ubiquitous form of agroforestry (Arroyo-Kalin, 2012; Denevan and Paddoch, 1987; van der Hammen and 
Rodríguez, 1996; see also Balée and Nolan, this volume; Ford and Clarke, this volume). On the other are the planting of doorstep orchards or 'house gardens', the deliberate planting or transplanting of foodstuffs in natural and human-made forest gaps and old settlements, and the promotion, tending, and/or harvesting of clumps of edible and useful plant species (Fig. 2a), domesticated or otherwise (e.g. Anderson and Posey, 1989; Balée, 1989; Cabalzar, 2010; Denevan and Paddoch, 1987; Hecht and Posey, 1989; Politis, 1996; Rival, 1998). Anthropic impact measurable over decadal to centennial scales arises in the plant species composition and structure of abandoned swiddens (Saldarriaga et al., 1988). Historical ecology studies document the existence of anthropic 'rainforest islands', which are composed of high densities of edible or useful plants (Balée, 2013). These are often interpreted as biotic legacies of past human practices of environmental manipulation. Many fieldworkers (myself included) have observed how these legacies are managed by current populations, who in some cases acknowledge they are the result of previous events of inhabitation (see Balée and Nolan, this volume; Ford and Clarke, this volume). Significantly, many examples have been linked to the presence of enriched anthropic soils associated with pre-Columbian settlement (see 'Soilscape Transformations').

Ter Steege et al. (2013) have recently argued that 1.4 per cent of the native tree species are dominant at the broad level of the Amazon basin. Many of the 'hyperdominant' species are palms with edible fruits (e.g. Euterpe oleracea, E. precatoria, Astrocaryum murumuru, Oenocarpus bataua, Attalea butyracea, A. phalerata, and Mauritia flexuosa) that are often associated with abandonded pre-Columbian settlement. Others are important edible or useful trees such as rubber (Hevea brasiliensis) and cocoa (Theobroma cacao). Ascertaining the extent to which this dominance is a result of pre- Columbian human activity, as well as establishing whether the species composition of rainforest can be interpreted as anthropic (Balée, 1989), demands both the concerted efforts of ecologists and anthropologists studying rainforest and indigenous traditional knowledge (Balée, 2010; Junqueira et al., 2011; Levis et al., 2012; Shepard and Ramirez, 2011) as well as that of palaeoecologists and archaeobotanists establishing the time- depth of these associations (Dickau et al., 2012; Iriarte et al., 2010). Recent studies highlight complex scenarios, such as pre-Columbian populations taking advantage of more open-vegetation formations to transform landscapes more effectively (Carson et al., 2014). Important challenges for these studies are the need to disentangle the effects of climate forcing from anthropic signals (including here if clear evidence of past fires can be linked to past human activity), as well as defining sampling grids that are appropriate to the scale of past human activity (Arroyo-Kalin, 2012; Iriarte et al., 2012; Mayle and Iriarte, 2014; Piperno et al., 2015; Stahl, 2015). However, the broader picture that emerges is that environments of Amazonia were locally but enduringly modified-at times intentionally and at times unwittingly-by the deliberate activity of pre-Columbian peoples.

\section{Soilscape Transformations}

By definition, anthrosols are soils whose formation and characteristics have been enduringly influenced by the material effects of human action (Arroyo-Kalin, 2014b; Woods, 2003). Anthrosol research in Amazonia has recognized the ubiquity of localized soil enrichment as a result of preColumbian settlement and cultivation activity. The best- known cases are soils known as Amazonian Dark Earths, which include two broad types known as terras pretas de índio and terras mulatas. 
Terras pretas are circumscribed expanses of dark-coloured and chemically enhanced soils within which are often found abundant pre-Columbian pottery remains (Fig. 2b). These expanses signal the location of pre-Columbian settlements and are believed to have formed as a consequence of the concentration of organic inputs-excrement, bone, organic matter, and combustion residuesrelated to kitchen middens, house gardens, dwelling structures, and pre-Columbian settlements. Decomposed or broken down in the soil, these inputs altered the pedogenetic (i.e. soil formation) pathways of parts of the soil mantle by raising soil $\mathrm{pH}$, increasing the ubiquity of sorption sites, concentrating reservoirs of specific desirable agricultural nutrients, and prompting the formation of stable organo-mineral complexes (Arroyo-Kalin, 2014a; Glaser and Birk, 2011; Sombroek, 1966). Terras mulatas are less chemically enhanced soils that in some cases surround patches of terras pretas. They have been interpreted as legacies of repeated burning around large settlements (Sombroek, 1966; Woods and McCann, 1999), as former outfields associated with the settlements signalled by terras pretas (Andrade, 1986; Arroyo-Kalin, 2010, 2012; Denevan, 2004), and as soil enrichment resulting from lower black carbon inputs, i.e. less burning associated with settlement activity (Hecht, 2003; Mora, 2003; Rebellato et al., 2009; Schmidt et al., 2014; Walker, 2011). Terras pretas and terras mulatas constitute two expressions of anthropic soil modification that reflect the spatial heterogeneity and palimpsest-like character of past human land-use (Erickson, 2003). They have acquired singular importance in Amazonian scholarship because their presence alongside the main rivers supports sixteenth-century $A D$ accounts of sedentary, demographically dense, and organizationally complex societies (Arroyo-Kalin, 2010; Denevan, 1996; Heckenberger et al., 1999; Kern et al., 2004; McMichael et al., 2014; Myers et al., 2003; Schmidt et al., 2014; Smith, 1980). Consequently, they touch on long-standing discussions about Amazonia's carrying capacity and its ability to sustain large populations against presumed inherent limitations of the soil mantle for agricultural intensification (Smith, 1980; Stahl, 2002). Their legacy value is manifest: terras pretas are prized to this day by Amazonian farmers (Fig. 2d) because they achieve higher yields of staple lowland cultivars such as Manihot esculenta, assist the growth of acid-intolerant crops such as Zea mays, and concentrate a high diversity of edible/useful fruit trees (Arroyo-Kalin, 2010; Balée, 1989; Clement et al., 2003; Fraser et al., 2011; German, 2003; Junqueira et al., 2011). However, as I point out below, it is still insufficiently clear whether these expanses were used for intensive cultivation in the past (Fig. 2c).

\section{Discussion}

\section{Anthropic Landscape Transformation and Landscape Evolution}

Some historical ecologists argue that environments become landscapes through cultural activity or take the stance that what defines 'the landscape' are its biotic components as modified by humans (Balée and Erickson, 2006; Walker, 2012). I believe this perspective is problematic because it reintroduces a dichotomy between culture and nature that renders 'landscape' as the landed equivalent of culture and retains 'environment' as the residual equivalent of nature. As regards the notion of environment this is wholly unnecessary since environments are fundamentally dynamic and historical: they are a series of interlocking organism-centred ecosystems that are transformed by populations of organisms over time (Patten, 2001). Environmental characteristics, therefore, are not fixed but instead historically contingent properties that are relative to specific populations: they 
constitute affordances (Gibson, 1982) that can constrain, structure, or enable particular lifeways. As regards landscapes, earth-scientific approaches to their study deserve to be incorporated into the core of historical ecological thinking. Earth- science thinking conceptualizes landscapes as fourdimensional assemblages of interrelated biotic and abiotic elements that exist materially (as well as cognitively, for organisms capable of cognition), are shaped by a complex interplay of external and internal dynamics and their associated feedback mechanisms (Chorley and Kennedy, 1971; Phillips, 1999) and, like all complex systems, are characterized by path-dependence (specific trajectories of transformation constrain the possible forms that subsequent states of a system can take). Landscapes so defined are landscapes quite regardless of any collisions with culture (Balée and Erickson, 2006: 2). This does not deny that human communities are able to transform, build, cognize, and memorialize their material settings, i.e. that they are capable of landscaping them. Human landscaping is inextricably tied to cosmology (as a received model of the world-in-theuniverse), to transmitted culture (as a specific set of practices that are employed across generations), and to social power and reproduction (in as much as they underpin the structure and continuity of populations). However, more than a series of additions, subtractions, alterations, or disturbances to the landscape, what matters in human landscaping is that landscape transformations endure over time. To be enduring, anthropic landscape modifications must first exceed system-specific thresholds (i.e. not be neutralized by negative feedbacks) and thus affect the broader trajectory of landscape evolution. This is well illustrated by causeways and canals in the flooding landscape of Amazonia (Fig. 1a), which may have locally affected process of drainage and sedimentation and thus altered existing pathways of alluvial evolution. Secondly, in order to be enduring, anthropic landscape modifications must also be resilient to subsequent transformations of the landscape system, such that at least some of their effects on the landscape are preserved as legacies or (so that we can reconstruct they used to operate) as environmental proxies. This is illustrated by raised fields built by pre-Columbian farmers in French Guiana (Fig. 1d), which ants colonies have helped to maintain after their abandonment over five centuries ago (McKey et al., 2010).

Whether intentional or incidental, human landscaping can be said to kick-start emergent pathways of landscape evolution. In Amazonia this is well exemplified by such emergent landscape transformations as Amazonian Dark Earths. Originating in the build-up of rubbish heaps, which often lead to localized change in soil $\mathrm{pH}$ and nutrient contents, these soil expanses become substrates that are more efficient for plant cultivation. These properties, in turn, govern the continued modification of these locales for agricultural activity (Fig. 2d), leading to amplification away from the original pathways of soil mantle evolution (Arroyo-Kalin, 2014a).

Returning to historical ecological scholarship, the 'palimpsest of continuous and discontinuous inhabitation by past and present peoples' (Balée and Erickson, 2006: 2) is, in practice, a property of the make-up of the landscape that, at one end, can be examined to reconstruct its preceding states (Butzer, 1982; French, 2003). At the other, it is an assemblage of properties that continue to affect its overall dynamics (Arroyo-Kalin, 2010; Balée, 1989; van der Leeuw and Redman, 2002). Thus, whilst the anthropocentric proposition advanced by historical ecology-that the human species is 'itself a principal mechanism of change in the natural world, a mechanism qualitatively as significant as natural selection' (Balée and Erickson, 2006: 5)-is undoubtedly pertinent, it is also perhaps excessively anthropocentric. Human practice, in all its complexity, is part of natural selection! What really matters however, is that some human landscaping practices can instigate emergent pathways 
of landscape evolution and that these pathways can endure as anthropic landscape legacies over time.

\section{Landscape Domestication and the Construction of the Human Niche}

Recent scholarship has strongly emphasized the notion of domesticated landscapes, with some authors preferring to expand the domus to encompass the landscape (Erickson, 2006a; Terrell et al., 2003) and others pinpointing events of conscious and directed human interventions that aim to intensify yields from plant or animal taxa, domesticated or otherwise (Clement, 1999, 2014; Clement et al., 2015; Erickson, 2000). These views differ in the importance accorded to irreversible morpho-genetic change as evidence for domestication (see also Fuller et al., 2014), yet share a common understanding that the reproduction of symbiotic relationships between human and other species did not occur in a vacuum and instead relied on enduring modifications of the landscape by human communities. These perspectives also converge with recent propositions advanced by Anthropocene studies (Roosevelt, 2013; Smith and Zeder, 2013) and human niche construction theory (Laland et al., 2000; Smith, 2007), both of which argue that human populations are especially effective ecosystem engineers that overwhelmingly modify the very selection pressures that affect themselves and other organisms.

Human niche construction theory can be expanded to include historical ecological studies of human legacy effects on the landscape. As I have suggested earlier, biotic legacies resulting from human modification, such as forests with significantly larger numbers of plant species promoted by past human action, as well as anthrosols like Amazonian Dark Earths, are anthropic biomes or anthromes (Ellis et al., 2013), i.e. human niches that have 'taken off' (Rowley-Conwy and Layton, 2011). The study of how these legacies developed in pre-Columbian Amazonia can help to elucidate whether dump heaps, modified soils, and raised or drained fields played significant roles in allowing the specialized cultivation of specific crops (Arroyo-Kalin, 2010; Iriarte et al., 2010). We can thus consider anthropic landscape transformations as essential dimensions of human niche construction, with potentially significant amplifying effects for past human sedentism, population growth, and social complexity. Landscape legacies also strongly underscore that human niche construction is a cumulative process that involves conditions bequeathed by prior inhabitants (Fig. $2 \mathrm{~d}$ ).

\section{Landesque Capital, Landscape Legacies, and Agricultural Intensification}

The notion of landesque capital has attracted significant recent attention (Håkansson and Widgren, 2014). Arguably the most widely employed formulation is still that offered by Brookfield (1984): that fixed agricultural installations, field systems, and major modifications to the soil can be considered 'landesque capital' because they have been intentionally produced to endure beyond the cropping cycle. In archaeology, landesque capital has often been recognized as terraces, field boundaries, and the like, and regarded as physical evidence for past agricultural intensification (Leach, 1999). Many of the Amazonian examples discussed previously - fruit tree groves associated with long- fallow slash-and-burn, field systems, anthrosols-might fit under a definition of landesque capital. The 
matter, however, is not so simple: cultural rainforests and anthropic soils, especially, reinstate important questions about what constitutes deliberate human behaviour and what constitutes the incidental effects of long-term, cumulative change (Arroyo-Kalin, 2014a; Balée, 2013).

Research in Amazonia documents that cultural forests have formed in different ways, including the repeated discard of fruit seeds at campsites reoccupied for short periods (Politis, 1996), the preservation of anthropic fruit tree stands that were once part of settlements (Balée, 1989), the regular management of natural stands of economically useful trees (management of patches of palms trees used for roof thatch is one such example), and deliberate agroforestry practices (Denevan and Paddoch, 1987). Even if they are planted for grandchildren and great-grandchildren (to slightly paraphrase van der Hammen and Rodríguez, 1996), their use as 'landscape capital', that is, as landed resources subject to appropriation, usufruct, management, and transformation, does not make them intentional outcomes 'built to last the cropping cycle'. An example of this misunderstanding is the frequent reference to terras pretas as evidence of landesque capital (Hornborg et al., 2014; Morrison, 2014; Widgren, 2008). However, all carefully documented archaeological cases of terras pretas evidence these were not purpose-built agricultural soils but rather anthrosols formed on substrates produced by former settlement activity. Sometimes these were buried beyond agricultural use during pre- Columbian times (Fig. 2c). Actual archaeological evidence for their use for agricultural purposes in pre-Columbian times, therefore, is not easy to isolate (Arroyo-Kalin, 2014a). This is not to deny that the formation of terras pretas may have included in situ practices related to soil enhancement and plant cultivation (Hecht, 2003; Schmidt et al., 2014) or that access to expanses of terras pretas may have been contested by different populations in the past (Arroyo-Kalin, 2010). However, rather than demonstrating that they were deliberately developed as a form of landesque capital, these possibilities are more about specific modifications to the soil mantle within a settlement as well as their legacy effect. Terras mulatas, which have been discussed both as legacy outcomes (Andrade, 1986; Sombroek, 1966) and as landesque capital (fire-intense, spatially restricted cultivation reliant on amendments to soils; see Arroyo-Kalin, 2012; Denevan, 2004; Schmidt et al., 2014), can be considered in a similar light: we cannot readily distinguish between the extent to which they record the effects of past practices of cultivation and actual attempts to intensify crop production though modifications beyond the cropping cycle.

To summarize, landscaping, landesque capital, and anthropic landscape legacies cannot be regarded as synonymous. A categorical distinction between these concepts is important because landscaping and landscape legacies are sometimes regarded as synonymous of landesque capital and used to support a still influential (Stump, 2013; see also Doolittle, this volume) Boserupian account of agricultural intensification led by population growth. Although most scholars would agree that overall population growth during the Holocene has been made possible by agricultural intensification (Ellis et al., 2013), critical discussion (Morrison, 2007) shows that apart from increasing productivity (Iriarte and Dickau, 2012; Walker, 2011), increased yields per unit of land can be driven by a host of additional factors beyond demographic increase. These include aggrandizing politics (Spencer and Redmond, 2004; Wiessner and Tumu, 1998), cultural choices associated with the adoption of specific cuisines (Fuller, 2005; Morrison, 2014), and expanding long-distance trade and exchange (Lathrap, 1973). The very notion that beyond-the-harvest investments on landed resources are only made when people are forced to do so, which is central to Boserup's model, fails to acknowledge that soil amendment and deliberate landscape modification associated with past 
agriculture can sometimes reflect attempts to prevent environmental degradation (French and Whitelaw, 1999), be less productive than assumed (Frederick, 2007), or represent a response to environmental stress induced by Holocene landscape change (Beach et al., 2009; Lombardo et al., 2011).

\section{Conclusion}

In the late nineteenth and early twentieth centuries, Charles Hartt and Curt Nimuendajú were among the first to observe and record the extent to which the landscape of Amazonia was marked by its past history of human inhabitation (Myers et al., 2003). In the late 20th century Balée (1989) advanced the claim that up to 11 per cent of Amazonia's rainforests included plant species that could indicate past human disturbance. The accuracy of this initial estimate continues to be reviewed through empirical research (Carson et al., 2014; Clement et al., 2015; Iriarte et al., 2010) but it is Balée's (1989: 13) provocative remarks about their historical significance that are of special interest: 'If we consider disturbance indicator trees and liana forests to be archaeological resources, the infrastructures of [contemporary] Arawete and Asurini societies thrive ... on the living artefacts of long-extinct cultures.' These remarks capture the very essence of why historical ecology is much more than diachronic modelling (Whitehead, 1998).

Above I have argued that an understanding of the landscape as a four-dimensional, physical, and historical entity, of the environment as a set of surrounding worlds that are co-constructed by organisms over time, of landscaping as a practice that enduringly materializes human practices in physical settings, and of landscape legacies as resilient outcomes of both deliberate and incidental landscape transformations, opens up a rich field of research for future historical ecological research. As the preceding discussion shows, much is lost if we conflate what humans deliberately do in the landscape with the incidental results of deliberate human action on the landscape. However, rather than simply recast Eidt's (1985) contrast between the anthropogenic and the anthropic, we should consider both landscaping and landscape legacies as dimensions of anthropogenic landscape transformations that may co-occur in particular landscape histories. This is not an attempt to avoid the question of intentionality at the eleventh hour but rather a desire to move on to the next, and in my view more interesting, question whether the enduring landscape effects of past human communities have affected the historical development of subsequent inhabitants of these landscapes. Or, to put it another way, whether we can introduce landscape history into the very core of human ecology and history.

\section{Acknowledgements}

The initial version of this chapter was presented at the session 'Developing Landscape Historical Ecologies: Integrating Theory with Applied Approaches' organized by Daryl Stump and Paul Lane at the 2009 Theoretical Archaeology Group (TAG) meeting in Durham, United Kingdom. To judge by its surviving stratigraphy-much of which resides in my laptop's hard drive-since then the manuscript has experienced many transformations yet resiliently retained and developed some of its core 
propositions. In reaching its present state, I would like to acknowledge a number of useful exchanges on the subject matter with Bill Balée, Charles Clement, Dorian Fuller, Michael Heckenberger, José Iriarte, Umberto Lombardo, Eduardo Neves, James Fraser, José Oliver, and Peter Stahl as well as the extraordinarily patient yet critical readings of Daryl Stump and Chris Isendahl, who kindly invited this contribution to the volume.

\section{Figure Captions}

Figure 1. Clockwise from upper left: (a) Aerial view of different types of pre-Columbian raised field systems. Llanos de Mojos, Beni, Bolivia (photo: Umberto Lombardo); (b) Fazenda Colorada geoglyph. Acre, Brazil (photo: Sanna Saunaluoma); (c) Mounds from the site of Sangay. Macas, Ecuador (photo: Stéphen Rostain); (d) Guianese pre- Columbian raised fields and their discoverer, Stéphen Rostain. French Guiana (photo: Manuel Arroyo-Kalin); (e) A deep pre-Columbian ditch at the Vila Gomes archaeological site. Borba, Amazonas, Brazil (photo: Claide de Paula Moraes).

Figure 2 Clockwise from upper left: (a) Mauritia carana leaves for house thatching are being transported from managed palm tree groves. Upper Rio Negro region, Amazonas, Brazil (photo: Aloisio Cabalzar); (b) Central Amazon Project excavations of the Hatahara terra preta expanse. Abundant pottery fragments show that these highly fertile soil expanses are former pre-Columbian settlements. Iranduba, Amazonas, Brazil (photo: Manuel Arroyo-Kalin); (c) The overburden of a deep pre-Columbian ditch at the Vila Gomes archaeological site burying a terra preta horizon. Borba, Amazonas, Brazil (photo: Claide de Paula Moraes); (d) Delegates to the 2nd International Meeting on Amazonian Archaeology visit an archaeological site with terras pretas used for a papaya plantation. Lago do Limão, Amazonas, Brazil (photo: Manuel Arroyo-Kalin).

Figures 

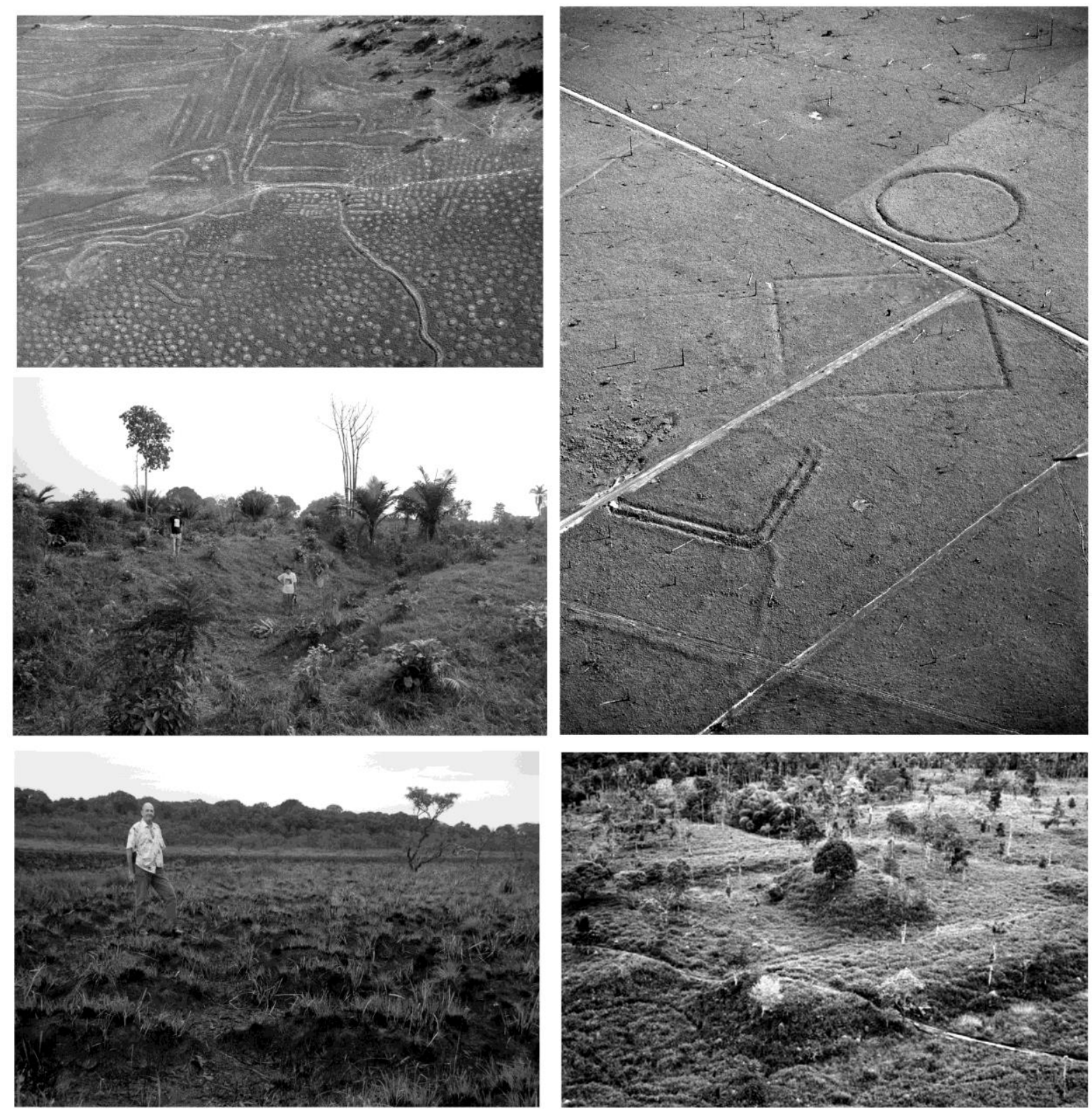

Figure 1 

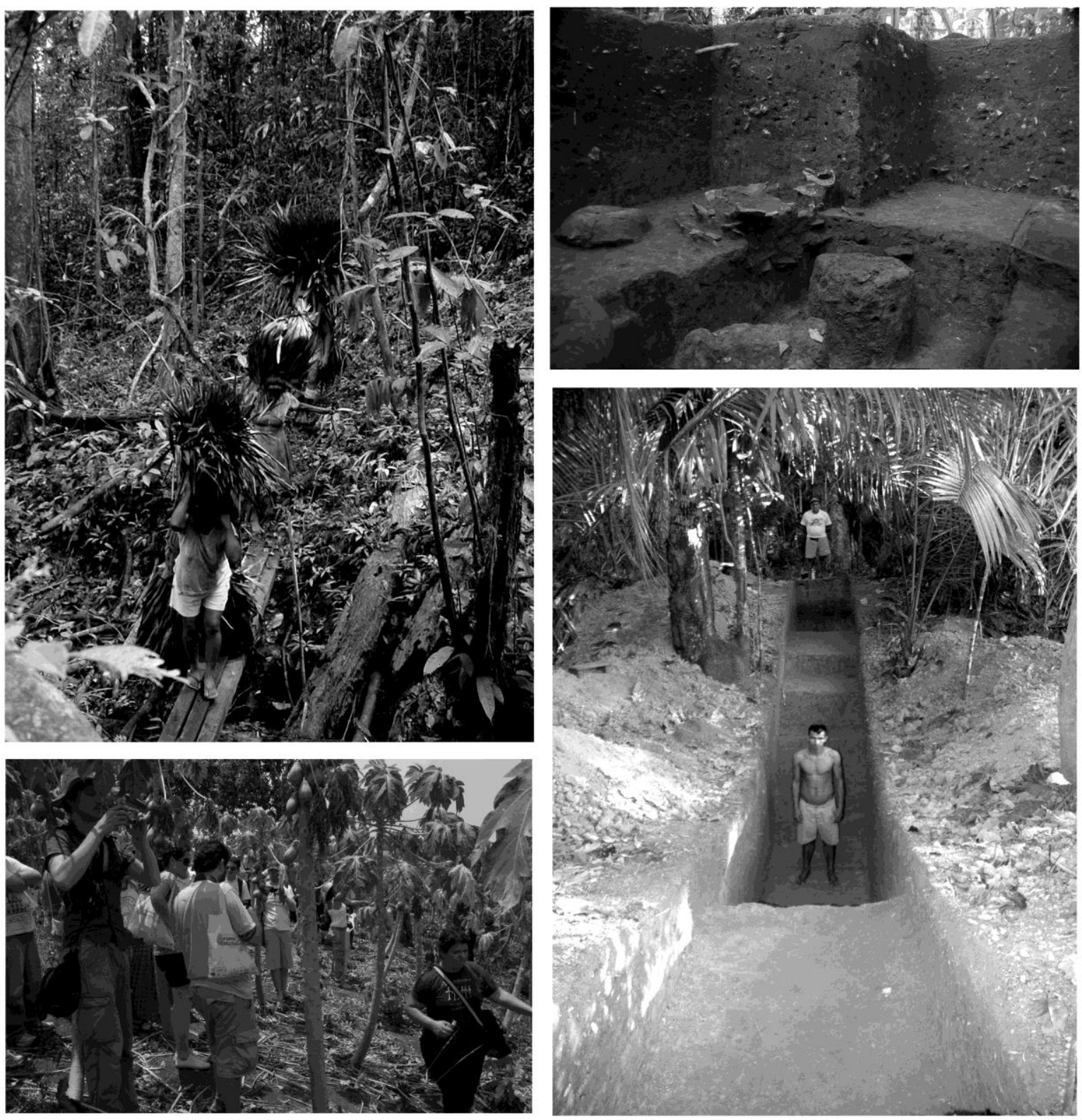

Figure 2

\section{References}

Anderson, A. B., and Posey, D. (1989). Management of a tropical scrub savanna by the Gorotire Kayapo of Brazil. In D. Posey and W. Balée (eds), Resource Management in Amazonia: Indigenous and Folk Strategies. Bronx, NY: New York Botanical Garden, 159- 173.

Andrade, Á. (1986). Investigación arqueológica de los antrosolos de Araracuara (Amazonas). Arqueología Colombiana 31: 1-101. 
Arroyo-Kalin, M. (2010). The Amazonian Formative: crop domestication and anthropogenic soils. Diversity 2(4): 473-504.

Arroyo-Kalin, M. (2012). Slash-burn-and-churn: landscape history and crop cultivation in preColumbian Amazonia. Quaternary International 249: 4-18.

Arroyo-Kalin, M. (2014a). Amazonian Dark Earths: Geoarchaeology. In C. Smith (ed.), Encyclopedia of Global Archaeology. New York: Springer, 168-178.

Arroyo-Kalin, M. (2014b). Anthropogenic sediments and soils: Geoarchaeology. In C. Smith (ed.), Encyclopedia of Global Archaeology. New York: Springer, 279-284.

Balée, W. (1989). The culture of Amazonian forests. In D. Posey and W. Balée (eds), Resource Management in Amazonia: Indigenous and Folk Strategies. Bronx, NY: New York Botanical Garden, $1-21$.

Balée, W. (1998). Historical ecology: premises and postulates. In W. Balée (ed.), Advances in Historical Ecology. New York: Columbia University Press, 13-27.

Balée, W. (2006). The research program of historical ecology. Annual Review of Anthropology 35: 75-98.

Balée, W. (2010). Contingent diversity on anthropic landscapes. Diversity 2(2): 163-181.

Balée, W. (2013). Cultural Forests of the Amazon: A Historical Ecology of People and their Landscape. Tuscaloosa, AL: University of Alabama Press.

Balée, W., and Erickson, C. L. (2006). Time, complexity, and historical ecology. In W. Balée and C. L. Erickson (eds), Time and Complexity in Historical Ecology: Studies in the Neotropical Lowlands. New York: Columbia University Press, 1-17. 
Beach, T., Luzzadder-Beach, S., Dunning, N., Jones, J., Lohse, J., Guderjan, J., Bozarth, S., Millspaugh, S., and Bhattacharya, T. (2009). A review of human and natural changes in Maya Lowland wetlands over the Holocene. Quaternary Science Reviews 28: 1710-1728.

Beckerman, S. (1987). Swidden in Amazonia and the Amazon rim. In B. L. Turner and S. B. Brush (eds), Comparative Farming Systems. New York: Guilford Press, 55-94.

Brookfield, H. (1984). Intensification revisited. Pacific Viewpoint 25(1): 15-44.

Brown, A., Toms, P., Carey, C., and Rhodes, E. (2013). Geomorphology of the Anthropocene: timetransgressive discontinuities of human-induced alluviation. Anthropocene 1: 3-13.

Butzer, K. W. (1982). Archaeology as Human Ecology. Cambridge: Cambridge University Press.

Cabalzar, A. (ed.) (2010). Manejo do Mundo: Conhecimentos e práticas dos povos indígenas do Rio Negro, noroeste Amazónico. São Paulo: Instituto Socioambiental / FOIRN.

Carson, J. F., Whitney, B. S., Mayle, F. E., Iriarte, J., Prümers, H., Soto, J. D., and Watling, J. (2014). Environmental impact of geometric earthwork construction in pre-Columbian Amazonia. Proceedings of the National Academy of Sciences of the United States of America 111(29): 1049710502.

Chorley, R. J., and Kennedy, B. (1971). Physical Geography: A Systems Approach. Englewood Cliffs, NJ: Prentice-Hall.

Clement, C. R. (1999). 1492 and the loss of Amazonian crop genetic resources. I: The relation between domestication and human population decline. Economic Botany 53(2): 188-202.

Clement, C. R. (2006). Fruit trees and the transition to food production in Amazonia. In W. Balée and C. L. Erickson (eds), Time and Complexity in Historical Ecology: Studies in the Neotropical Lowlands. New York: Columbia University Press, 165-185.

Clement, C. R. (2014). Landscape domestication and archaeology. In C. Smith (ed.), Encyclopedia of Global Archaeology. New York: Springer, 4388-4394. 
Clement, C. R., Cristo-Araújo, M. D., D’Eeckenbrugge, G. C., Pereira, A. A., and Picanço- Rodrigues, D. (2010). Origin and domestication of native Amazonian crops. Diversity 2(1): 72-106.

Clement, C. R., McCann, J. M., and Smith, N. J. (2003). Agrobiodiversity in Amazonia and its relationship with dark earths. In J. Lehmann, D. C. Kern, B. Glaser, and W. Woods (eds), Amazonian Dark Earths: Origin, Properties, Management. Dordrecht: Kluwer, 159- 178.

Clement, C. R., Rival, L., and Cole, D. M. (2009). Domestication of peach palm: the roles of human mobility and migration. In M. N. Alexiades (ed.), Shifting Spaces, Changing Times: Mobility, Migration and Displacement in Indigenous Lowland South America. London: Berghahn, 117-140.

Clement, C. R., Denevan, W. M., Heckenberger, M. J., Junqueira, A. B., Neves, E. G., Teixeira, W. G., and Woods, W. I. (2015). The domestication of Amazonia before European conquest. Proceedings of the Royal Society B: Biological Sciences 282(1812): 20150813.

Crumley, C. L. (1994). Historical ecology: a multidimensional ecological orientation. In C. L. Crumley (ed.), Historical Ecology: Cultural Knowledge and Changing Landscapes. Santa Fe, NM: School of American Research Press, 1-16.

Denevan, W. M. (1996). A bluff model of riverine settlement in prehistoric Amazonia. Annals of the Association of American Geographers 86(4): 654-681.

Denevan, W. M. (2004). Semi-intensive pre-European cultivation and the origins of anthropogenic dark earths in Amazonia. In B. Glaser and W. I. Woods (eds), Amazonian Dark Earths: Explorations in Space and Time. Berlin and London: Springer, 135-143.

Denevan, W. M., and Paddoch, C. (1987). Swidden-fallow agroforestry in the Peruvian Amazon. Advances in Economic Botany 5: 1-107.

Dickau, R., Bruno, M. C., Iriarte, J., Prümers, H., Betancourt, C. J., Holst, I., and Mayle, F. E. (2012). Diversity of cultivars and other plant resources used at habitation sites in the Llanos de Mojos, Beni, Bolivia: evidence from macrobotanical remains, starch grains, and phytoliths. Journal of Archaeological Science 39(2): 357-370. 
Eidt, R. C. (1985). Theoretical and practical considerations in the analysis of anthrosols. In J. G. Rapp (ed.), Archaeological Geology. New Haven, CT: Yale University Press, 155- 190.

Ellis, E. C., Kaplan, J. O., Fuller, D. Q., Varus, S., Goldwijk, K. K., and Verburg, P. H. (2013). Used planet: a global history. Proceedings of the National Academy of Sciences of the United States of America 110(20): 7978-7985.

Erickson, C. L. (2000). An artificial landscape-scale fishery in the Bolivian Amazon. Nature 408: 190193.

Erickson, C. L. (2003). Historical ecology and future explorations. In J. Lehmann, D. Kern, B. Glaser, and W. Woods (eds), Amazonian Dark Earths: Origins, Properties and Management. Dordrecht: Kluwer, 455-500.

Erickson, C. L. (2006a). The domesticated landscapes of the Bolivian Amazon. In W. Balée and C. L. Erickson (eds), Time and Complexity in Historical Ecology: Studies in the Neotropical Lowlands. New York: Columbia University Press, 235-278.

Erickson, C. L. (2006b). Intensification, political economy and the farming community: in defense of a bottom-up approach. In J. Marcus and C. Stanish (eds), Agricultural Strategies. Los Angeles, CA: Cotsen Institute of Archaeology, 233-265.

Erickson, C. L. (2008). Amazonia: the historical ecology of a domesticated landscape. In H. Silverman and W. Isbell (eds), The Handbook of South American Archaeology. New York: Springer, 157-183.

Fraser, J., Junqueira, A., and Clement, C. (2011). Homegardens on Amazonian Dark Earths, nonanthropogenic upland, and floodplain soils along the Brazilian Middle Madeira River exhibit diverging agrobiodiversity. Economic Botany 65: 1-12.

Frederick, C. D. (2007). Chinampa cultivation in the basin of Mexico: observations on the evolution of form and function. In T. L. Thurston and C. T. Fisher (eds), Seeking a Richer Harvest: The Archaeology of Subsistence Intensification, Innovation and Change. New York: Springer, 107-124.

French, C. A. I. (2003). Geoarchaeology in Action: Studies in Soil Micromorphology and Landscape Evolution. London: Routledge. 
French, C. A. I., and Whitelaw, T. M. (1999). Soil erosion, agricultural terracing and site formation processes at Markiani, Amorgos, Greece: the micromorphological perspective. Geoarchaeology 14(2): 151-189.

Fuller, D. Q. (2005). Ceramics, seeds and culinary change in prehistoric India. Antiquity 79: 761-777.

Fuller, D. Q., Denham, T., Arroyo-Kalin, M., Lucas, L., Qin, L., Allaby, R., and Purugganan, M. D. (2014). Convergent evolution and parallelism in plant domestication revealed by an expanding archaeological record. Proceedings of the National Academy of Sciences of the United States of America 111(17): 6147-6152.

German, L. A. (2003). Historical contingencies in the coevolution of environment and livelihood: contributions to the debate on Amazonian Black Earth. Geoderma 111(3-4): 307-331.

Gibson, J. J. (1982). Notes on affordances. In E. Reed and R. Jones (eds), Reasons for Realism: The Selected Essays of James J. Gibson. Hillsdale, NJ: Erlbaum, 401-418. Glaser, B., and Birk, J. J. (2011). State of the scientific knowledge on properties and genesis of Anthropogenic Dark Earths in Central Amazonia. Geochimica et Cosmochimica Acta 82: 39-51.

Håkansson, N. T., and Widgren, M. (eds) (2014). Landesque Capital: The Historical Ecology of Enduring Landscape Modifications. Walnut Creek, CA: Left Coast Press.

Harris, D. R. (1971). The ecology of swidden cultivation in the Upper Orinoco Rain Forest, Venezuela. Geographical Review 61(4): 475-495.

Hecht, S. B. (2003). Indigenous soil management and the creation of Amazonian dark earths: implications of Kayapó practices. In J. Lehmann, D. C. Kern, B. Glaser, and W. Woods (eds), Amazonian Dark Earths: Origin, Properties, Management. Dordrecht: Kluwer, 355-372.

Hecht, S. B., and Posey, D. (1989). Preliminary results on soil management techniques of the Kayapó indians. In D. Posey and W. Balée (eds), Resource Management in Amazonia: Indigenous and Folk Strategies. Bronx, NY: New York Botanical Garden, 174-188. 
Heckenberger, M. J. (2008). Amazonian mosaics: identity, interaction, and integration in the tropical forest. In H. Silverman and W. Isbell (eds), Handbook of South American Archaeology. New York: Springer, 941-961.

Heckenberger, M. J., Petersen, J. B., and Neves, E. G. (1999). Village size and permanence in Amazonia: two archaeological examples from Brazil. Latin American Antiquity 10(4): 353-376.

Hornborg, A., Eriksen, L., and Bogadóttir, R. (2014). Correlating landesque capital and ethnopolitical integration in pre-Columbian South America. In N. T. Håkansson and M. Widgren (eds), Landesque Capital: The Historical Ecology of Enduring Landscape Modifications. Walnut Creek, CA: Left Coast Press, 215-231.

Iriarte, J., and Dickau, R. (2012). As culturas do milho? Arqueobotânica de las sociedades hidráulicas das terras baixas sul-americanas. Amazônica 4: 30-58.

Iriarte, J., Glaser, B., Watling, J., Wainwright, A., Birk, J. J., Renard, D., Rostain, S., and McKey, D. (2010). Late Holocene Neotropical agricultural landscapes: phytolith and stable carbon isotope analysis of raised fields from French Guianan coastal savannahs. Journal of Archaeological Science 37(12): 2984-2994.

Iriarte, J., Power, M. J., Rostain, S., Mayle, F. E., Jones, H., Watling, J., Whitney, B. S., and McKey, D. B. (2012). Fire-free land use in pre-1492 Amazonian savannas. Proceedings of the National Academy of Sciences of the United States of America 109(17): 6473-6478.

Junqueira, A., Shepard, G., and Clement, C. (2011). Secondary forests on anthropogenic soils of the Middle Madeira River: valuation, local knowledge, and landscape domestication in Brazilian Amazonia. Economic Botany 65(1): 85-99.

Kern, D. C., Costa, M. L. D., and Frazão, F. J. L. (2004). Evolution of the scientific knowledge regarding archaeological black earths of Amazonia. In B. Glaser and W. I. Woods (eds), Amazonian Dark Earths: Explorations in Space and Time. Berlin and London: Springer, 19-28.

Laland, K. N., Odling-Smee, J., and Feldman, M. W. (2000). Niche construction, biological evolution and cultural change. Behavioral and Brain Sciences 23(1): 131-146. 
Lathrap, D. W. (1973). The antiquity and importance of long-distance trade relationships in the moist tropics of pre-Columbian South America. World Archaeology 5(2): 170-186.

Leach, H. (1999). Intensification in the Pacific: a critique of the archaeological criteria and their application. Current Anthropology 40(3): 311-340.

Levis, C., De Souza, P. F., Schietti, J., Emilio, T., Pinto, J. L. P. D. V., Clement, C. R., and Costa, F. R. C. (2012). Historical human footprint on modern tree species composition in the Purus-Madeira interfluve, Central Amazonia. PlosOne 7: e48559.

Lombardo, U., Canal-Beeby, E., Fehr, S., and Veit, H. (2011). Raised fields in the Bolivian Amazonia: a prehistoric green revolution or a flood risk mitigation strategy? Journal of Archaeological Science 38(3): 502-512.

Lombardo, U., and Prümers, H. (2010). Pre-Columbian human occupation patterns in the eastern plains of the Llanos de Moxos, Bolivian Amazonia. Journal of Archaeological Science 37(8): 18751885.

McKey, D., Rostain, S., Iriarte, J., Glaser, B., Birk, J. J., Holst, I., and Renard, D. (2010). Pre-Columbian agricultural landscapes, ecosystem engineers, and self-organized patchiness in Amazonia.

Proceedings of the National Academy of Sciences of the United States of America 107(17): 78237828.

McMichael, C., Palace, M., Bush, M., Braswell, B., Hagen, S., Neves, E., Silman, M., Tamanaha, E., and Czarnecki, C. (2014). Predicting pre-Columbian anthropogenic soils in Amazonia. Proceedings of the Royal Society B: Biological Sciences 281(1777): 20132475.

Marcus, J., and Stanish, C. (eds) (2006). Agricultural Strategies. Los Angeles, CA: Cotsen Institute of Archaeology.

Mayle, F. E., and Iriarte, J. (2014). Integrated palaeoecology and archaeology: a powerful approach for understanding pre-Columbian Amazonia. Journal of Archaeological Science 51: 54-64.

Mora, S. (2003). Early Inhabitants of the Amazonian Tropical Rain Forest: A Study of Humans and Environmental Dynamics. Pittsburg, PA: University of Pittsburg Press. 
Moraes, C. D. P., and Neves, E. G. (2012). O ano 1000: adensamento populacional, interação e conflito na Amazônia Central. Amazônica 4: 122-148.

Morcote-Ríos, G., Aceituno, F. J., and Sicard, T. L. (2014). Recolectores del Holoceno Temprano en la Floresta Amazónica Colombiana. In S. Rostain (ed.), Antes de Orellana. Actas del 3er Encuentro Internacional de Arqueología Amazónica. Quito: IFEA/FLACSO/ US Embassy, 39-50.

Morrison, K. D. (2007). Rethinking intensification: power relations and scales of analysis in precolonial South India. In T. L. Thurston and C. T. Fisher (eds), Seeking a Richer Harvest: The Archaeology of Subsistence Intensification, Innovation and Change. New York: Springer, 235-249.

Morrison, K. D. (2014). Capital-esque landscapes: the historical ecology of enduring landscape modifications. In N. T. Håkansson and M. Widgren (eds), Landesque Capital: The Historical Ecology of Enduring Landscape Modifications. Walnut Creek, CA: Left Coast Press, 49-74.

Myers, T. P., Denevan, W. M., Winklerprins, A., and Porro, A. (2003). Historical perspectives on Amazonian dark earths. In J. Lehmann, D. Kern, B. Glaser, and W. Woods (eds), Amazonian Dark Earths: Origins, Properties and Management. Dordrecht: Kluwer, 29-50.

Neves, E. G. (2013). Was agriculture a key productive activity in pre-colonial Amazonia? The stable productive basis for social equality in the Central Amazon. In E. S. Brondízio and E. F. Moran (eds), Human-Environment Interactions: Current and Future Directions. New York: Springer, 371-388.

Patten, B. C. (2001). Jakob von Uexkull and the theory of environs. Semiotica 134: 423-443.

Phillips, J. D. (1999). Divergence, convergence, and self-organization in landscapes. Annals of the Association of American Geographers 89(3): 466-488.

Pickersgill, B. (2007). Domestication of plants in the Americas: insights from Mendelian and molecular genetics. Annals of Botany 100: 925-940.

Piperno, D. R., McMichael, C. N., and Bush, M. B. (2015). Amazonia and the Anthropocene: what was the spatial extent and intensity of human landscape modification in the Amazon Basin at the end of prehistory? The Holocene 25(10): 1588-1597.

Piperno, D. R., and Pearsall, D. (1998). The Origins of Agriculture in the Lowland Neotropics. San Diego, CA: Academic Press. 
Politis, G. (1996). Moving to produce: Nukak mobility and settlement patterns in Amazonia. World Archaeology 27(3): 492-511.

Posey, D. (1985). Indigenous management of tropical forest ecosystems: the case of the Kayapó indians of the Brazilian Amazon. Agroforestry Systems 3(2): 139-158.

Rebellato, L., Woods, W. I., and Neves, E. G. (2009). Pre-Columbian settlement dynamics in the Central Amazon. In W. I. Woods, W. G. Texeira, J. Lehmann, C. Steiner, A. M. G. A. Winklerprins, and L. Rebellato (eds), Amazonian Dark Earths: Wim Sombroek's Vision. New York: Springer, 15-31.

Rival, L. (1998). Domestication as a historical and symbolic process: wild gardens and cultivated forests in the Ecuadorian Amazon. In W. Balée (ed.), Advances in Historical Ecology. New York: Columbia University Press, 232-250.

Roosevelt, A. C. (1991). Moundbuilders of the Amazon: Geophysical Archaeology on Marajo Island, Brazil. New York: Academic Press.

Roosevelt, A. C. (2013). The Amazon and the Anthropocene: 13,000 years of human influence in a tropical rainforest. Anthropocene 4: 69-87.

Rostain, S. (2008). Agricultural earthworks on the French Guiana coast. In H. Silverman and W. Isbell (eds), Handbook of South American Archaeology. New York: Springer, 217- 233.

Rostain, S. (2012). Between sierra and selva: landscape transformations in upper Ecuadorian Amazonia. Quaternary International 249: 31-42.

Rowley-Conwy, P., and Layton, R. (2011). Foraging and farming as niche construction: stable and unstable adaptations. Philosophical Transactions of the Royal Society of London. Series B: Biological Sciences 366(1566): 849-862.

Saldarriaga, J. G., West, D. C., Tharp, M. L., and Uhl, C. (1988). Long-term chronosequence of forest succession in the upper Rio Negro of Colombia and Venezuela. Journal of Ecology 76(4): 938-958. 
Schaan, D. P. (2008). The non-agricultural chiefdoms of Marajo Island. In H. Silverman and W. Isbell (eds), Handbook of South American Archaeology. New York: Springer, 338- 357.

Schaan, D. P. (2011). Sacred Geographies of Ancient Amazonia: Historical Ecology of Social Complexity. Walnut Creek, CA: Left Coast Press.

Schmidt, M. J., Rapp Py-Daniel, A., Moraes, C. D. P., Valle, R. B. M., Caromano, C. F., Texeira, W. G., Barbosa, C. A., Fonseca, J. A., Magalhães, M. P., Santos, D. S. D. C., Silva, R. D. S. E., Guapindaia, V. L., Moraes, B., Lima, H. P., Neves, E. G., and Heckenberger, M. J. (2014). Dark earths and the human built landscape in Amazonia: a widespread pattern of anthrosol formation. Journal of Archaeological Science 42: 152-165.

Shepard, G. H., and Ramirez, H. (2011). 'Made in Brazil': human dispersal of the Brazil nut (Bertholletia excelsa, Lecythidaceae) in Ancient Amazonia. Economic Botany 65(1): 44-65.

Smith, B. D. (2007). Niche construction and the behavioral context of plant and animal domestication. Evolutionary Anthropology: Issues, News, and Reviews 16(5): 188-199.

Smith, B. D., and Zeder, M. (2013). The onset of the Anthropocene. Anthropocene 4: 8-13.

Smith, N. K. H. (1980). Anthrosols and human carrying capacity in Amazonia. Annals of the Association of American Geographers 70(4): 553-566.

Smith, N. K. H. (2014). A rainforest cornucopia: the cultural importance of native fruits in Amazonia. In S. Rostain (ed.), Amazonía. Memorias de las Conferencias Magistrales del 3er Encuentro Internacional de Arqueología Amazónica. Quito: Ministerio Coordinador de Conocimiento y Talento Humano/IKIAM, 31-50.

Sombroek, W. G. (1966). Amazon Soils: A Reconnaissance of the Soils of the Brazilian Amazon region. Wageningen: Centre for Agricultural Publications and Documentation.

Spencer, C. S., and Redmond, E. M. (2004). Prehispanic causeways and regional politics in the llanos of Barinas, Venezuela. Latin American Antiquity 9(2): 95-110.

Stahl, P. W. (1996). Holocene biodiversity: an archaeological perspective from the Americas. Annual Review of Anthropology 25: 105-126. 
Stahl, P. W. (2002). Paradigms in paradise: revising standard Amazonian prehistory. Review of Archaeology 23: 39-51.

Stahl, P. W. (2015). Interpreting interfluvial landscape transformations in the pre- Columbian Amazon. The Holocene, 25(10):1598-1603.

Stenborg, P., Schaan, D. P., Isendahl, C., Söderström, M., Eriksson, J., Amaral, M., and Olvmo, M. (2014). The Cultivated Wilderness Project: hinterland archaeology in the Belterra Region, Pará, Brasil. In S. Rostain (ed.), Before Orellana: Proceedings of the 3rd International Meeting on Amazonian Archaeology. Quito: IFEA/FLACSO/US Embassy, 149-155.

Stump, D. (2013). The role of agricultural and environmental history in developmental discourse in eastern Africa. In M. Davies and F. Nkirote-M'mbogori (eds), Humans and the Environment: New Archaeological Perspectives for the 21st Century. Oxford: Oxford University Press, 171-182.

Terrell, J. E., Hart, J. P., Barut, S., Cellinese, N., Curet, A., Denham, T., Kusimba, C. M., Latinis, K., Oka, R., Palka, J., Pohl, M. E. D., Pope, K. O., Williams, P. R., Haines, H., and Staller, J. E. (2003). Domesticated landscapes: the subsistence ecology of plant and animal domestication. Journal of Archaeological Method and Theory 10(4): 323-368.

Ter Steege, H., Pitman, N. C. A., Sabatier, D., ... Silman, M. R. (2013). Hyperdominance in the Amazonian tree flora. Science 342(6156): 325.

van der Hammen, M. C., and Rodríguez, C. A. (1996). Sembrar para nietos y bisnietos: manejo de la sucesión forestal por los indígenas Yukuna-Matapí de la Amazonía Colombiana. Cespedesia 21: 257270.

van der Leeuw, S., and Redman, C. L. (2002). Placing archaeology at the center of socio- natural studies. American Antiquity 67(4): 597-605.

Walker, J. H. (2011). Social implications from agricultural taskscapes in the southwestern Amazon. Latin American Antiquity 22(3): 275-296. 
Walker, J. H. (2012). Recent landscape archaeology in South America. Journal of Archaeological Research 20(4): 309-355.

Whitehead, N. L. (1998). Ecological history and historical ecology: diachronic modeling versus historical explanation. In W. Balée (ed.), Advances in Historical Ecology. New York: Columbia University Press, 30-40.

Widgren, M. (2008). Pre-colonial landesque capital: a global perspective. In A. Hornborg, J. MartinezAlier, and J. R. McNeill (eds), Rethinking Environmental History: World- System History and Global Environmental Change. Walnut Creek, CA: AltaMira Press, 61- 77.

Wiessner, P., and Tumu, A. (1998). Historical Vines: Enga Networks of Exchange, Ritual and Warfare in Papua New Guinea. Washington, DC: Smithsonian Institution Press.

Wilkinson, T. J. (2003). Archaeological Landscapes of the Near East. Tucson, AZ: University of Arizona Press.

Woods, W. I. (2003). Development of anthrosol research. In J. Lehmann, D. Kern, B. Glaser, and W. Woods (eds), Amazonian Dark Earths: Origins, Properties and Management. Dordrecht: Kluwer, 314.

Woods, W. I., and McCann, J. M. (1999). The anthropogenic origin and persistence of Amazonian dark earths. Yearbook, Conference of Latin Americanist Geographers 25: 7-14. 